\title{
Can Resilience be Reconciled with Globalization and the Increasingly Complex Conditions of Resource Degradation in Asian Coastal Regions?
}

\author{
Derek Armitage $^{1}$ and Derek Johnson ${ }^{2}$
}

\begin{abstract}
This paper explores the relationship between resilience and globalization. We are concerned, most importantly, with whether resilience is a suitable conceptual framework for natural resource management in the context of the rapid changes and disruptions that globalization causes in social-ecological systems. Although theoretical in scope, we ground this analysis using our experiences in two Asian coastal areas: Junagadh District in Gujarat State, India and Banawa Selatan, in Central Sulawesi, Indonesia. We present the histories of resource exploitation in the two areas, and we attempt to combine a resilience perspective with close attention to the impact of globalization. Our efforts serve as a basis from which to examine the conceptual and practical compatibility of resilience with globalization. The first challenge we address is epistemological: given that resilience and globalization have roots in different disciplines, do they share a sufficiently common perception of change and human action to be compatible? Second, we address the issue of how resilience can be a viable management objective in the rapidly changing context of globalization. We identify scale as particularly important in this regard.
\end{abstract}

Key Words: globalization; resilience; complexity; India; Indonesia; resource management; coastal management; social-ecological system; sustainability

\section{INTRODUCTION}

Conclusive evidence of a crisis in global fish populations is one of the most significant demonstrations of the problematic nature of human use of the world's coastal and marine environments (Pauly et al. 2002, FAO 2005). Other indications of stress in these areas are increasing levels of coastal and marine pollution, destruction of coastal habitat for development, and increasing human population densities in coastal areas (Vitousek et al. 1997). The impacts of the crisis in global fisheries and other pressures on the coastal zone have been severe for natural resource-dependent coastal communities, many of which are facing increasingly tenuous livelihood prospects (Visser 2004).

One response to the growing ecological crisis of coastal and marine zones is resilience thinking, which challenges many of the assumptions of the dominant approaches to natural resource management
(Holling and Meffe 1996, Gunderson and Holling 2002). Resilience thinking has emerged as a conceptual framework with which to understand change and the multiple, cross-scale interactions of social-ecological systems (Gunderson and Holling 2002, Berkes et al. 2003). Although grounded in the ecological sciences (Holling 1973), resilience has increasingly been tested and applied by natural and social scientists to examine a range of ecological communities (Gunderson 2003), linked socialecological systems (Berkes and Folke 1998, Berkes et al. 2003), and institutional and organizational arrangements (Gunderson and Holling 2002, Anderies et al. 2004).

Resilience thinking has coincided with an explosion of academic and popular interest in globalization as a way to label the rapid and often unsettling change stimulated by increased global interconnection (Speth 2003). As with resilience, the focus of social scientists working within the general area of globalization has been change. The social science 
of globalization extends to ecological change, but as befits its disciplinary places of departure, that area is secondary to socio-cultural, economic, and political change (Held and McGrew 2003, Zimmerer and Bassett 2003, Robbins 2004). We use the term globalization, in this paper, to refer to the diverse set of processes that drive social-ecological change at multiple scales. We single out the economic forces and ideas that drive globalization, or capitalism and modernity as we label them.

Both resilience and globalization are perspectives that can guide comprehensive analyses of change and resource degradation. Despite their current prominence and the great emphasis put on crossscale interactions within complex human ecosystems analysis, the two terms are not, in general, explicitly paired in analyses of change in social and ecological systems, although recent works are beginning to do so. For example, Adger (2000) situates the resilience of local human ecosystems within the context of global markets and other larger scales without explicitly using the term globalization, whereas other analyses of socialecological change refer to the drivers of economic globalization and modernity (see Ostrom et al. 2002, Berkes et al. 2003).

We attempt to use these concepts in tandem in the analysis of two coastal Asian case studies: Junagadh District in Gujarat State, India and Banawa Selatan in Central Sulawesi, Indonesia. We are interested, most importantly, in determining whether resilience is a suitable conceptual framework for natural resource management in the context of the rapid changes and disruptions that globalization has caused in these social-ecological systems. Our first concern is epistemological: given that resilience and globalization have roots in different disciplines, do they share a sufficiently common perception of change and human action to be compatible? Our second concern builds on the first. If we accept epistemological compatibility, or at least the need to work towards it, is resilience a practical guide for resource management given the effects of globalization? Alternatively, is resilience just a metaphor to help us understand the interactions and viability of linked social-ecological systems?

\section{LINKING RESILIENCE AND GLOBALIZATION}

Social and ecological systems are characterized by co-evolutionary, nonlinear interactions. Efforts to understand such processes have led to the emergence of resilience as a way in which to understand linked social-ecological systems. Detailed descriptions of resilience and allied concepts are provided elsewhere (Gunderson and Holling 2002, Berkes et al. 2003), and we do not attempt to summarize that literature here. Rather, to examine the relationship between resilience and globalization, we focus on a few of the core constructs that frame resilience theory, notably the slow- and fast-moving variables that interact within the adaptive cycle, and the associated implications these have on management decisions.

Berkes et al (2003), identify three central features of resilience: (1) the ability of a system to absorb or buffer disturbances and still maintain its core attributes, (2) the ability of the system to selforganize, and (3) the capacity for learning and adaptation in the context of change. Walker et al (2002) describe resilience as the potential of a system to remain in a particular configuration, and maintain feedbacks, functions, and an ability to reorganize following disturbance-driven change. Resilience, thus, provides a measure of the amount of disturbance that will cause a system to shift from one set of mutually reinforcing processes and structures to some alternative set of processes and structures (see Holling 1973). In practical terms, an understanding of resilience enables analysts and decision makers to identify the likelihood of shifts or transitions among different system configurations (Peterson 2000).

The adaptive cycle provides a way of understanding resilience and the likelihood of system shifts. As a metaphorical tool, the adaptive cycle highlights as common in the evolutionary cycles of all natural and social systems, processes of growth, conservation, destruction, and reorganization (Gunderson and Holling 2002). According to Peterson (2000), the adaptive cycle, thus, serves to illustrate the way in which certain variables interact to reinforce one another and build structure or organization, i.e., growth and conservation phases. In turn, the persistence of the system becomes dependent on this organization, making it increasingly rigid and vulnerable to exogenous and/ or endogenous disturbance. As a result of such 
disturbances, this rigid system will eventually collapse and provide new opportunities for the remaining system structures and processes to reorganize, often with inputs from other scales, and begin a new cycle of building structure and organization, i.e., destruction and reorganization phases. Thus, the adaptive cycle highlights two forms of change: (1) the slow and incremental processes of growth and accumulation, and (2) the rapid and sudden processes of destruction and reorganization in response to disturbance (Gunderson and Holling 2002).

However, adaptive cycles do not function in isolation, rather they exist as nested, connected cycles occurring in multiple domains. Resilience is an outcome of the communication among these nested cycles and the interactions among the slowand fast-moving variables that influence the four stages of growth, conservation, destruction, and reorganization (Holling 2001). Slow-moving variables, operating at larger temporal and spatial scales, e.g., spatial connectivity in forested ecosystems, or long-standing institutions and/or values in social systems, promote stability, maintain the legacies required for natural processes of evolution or adaptation, and foster a "memory" effect. However, within the stable domains created by slow-moving variables, fast variables, e.g., insect outbreaks in forest ecosystems or individual preferences in social systems, provide the novelty for experimentation upon which adaptation depends (Ruitenbeek and Cartier 2001). Importantly, fast variables operating at shorter temporal and smaller spatial scales can overwhelm slower variables, thus precipitating a period of "revolt" or creative destruction and eventual reorganization as system structures and processes pass through the stages of the adaptive cycle. Therefore, as noted by Gunderson and Holling (2002), there are two critical connections that influence resilience and adaptive capacity: (1) the memory connection among nested adaptive cycles that provides conditions of renewal and stability, furnished by the accumulated potential stored in larger, slower variables and cycles; and (2) the revolt connection, in which smaller variables and cycles destabilize larger, slower variables and cycles at a vulnerable stage, i.e., when they become too rigid, and generate a process of rapid change and a potential system flip or transformation.

There are numerous implications for management planning that arise from this understanding of adaptive cycles and resilience. Efforts to foster resilience in coupled social-ecological systems depend on identifying and maintaining those crucial slow variables that collectively determine the dynamics of the system. It is essential to understand the processes that may destabilize these variables, and in particular, the points at which thresholds are reached and fundamental system changes occur. Thus, a primary goal for planners and managers should be to keep linked social-ecological systems from moving towards, or further into, system states or conditions that meet neither ecological nor socioeconomic sustainability criteria, or in systems terminology, keeping the system from "flipping" into an alternative and possibly degraded state.

As illustrated above, an important construct of resilience is the identification and preservation of those slow variables that enable linked socialecological systems to renew and reorganize along a desirable trajectory, from a human perspective, in the wake of a major disturbance. However, we posit, that evidence of rapid change and disruption, created by the process of globalization, reveals a potentially problematic tension with this theoretical construct. Specifically, when used as an organizational framework, can resilience be reconciled with the rapid change and disruption that globalization imparts on coupled social-ecological systems?

Globalization has become a widely used term to make sense of the current time of rapid and unsettling change, and has generated an enormous volume of academic and popular literature (Held and McGrew 2003). The spread of globalization as a concept reflects a sense, long anticipated in the writings of commentators such as Marx who stated that we live in an unprecedented time of global interconnection and transformation. Globalization is an extremely complex process that has many manifestations and touches on all spheres of human activity. However, there is no single dominant conceptual framework for globalization as there is for thinking about resilience. Therefore, we focus on the dimensions of globalization that are central to understanding the processes of change in the regions we studied. We touch on some of the key drivers of globalization, important characteristics of the phenomenon, and its spatial consequences.

The dynamism of globalization is rooted in the intellectual currents and economic forces that coalesced during enlightenment and industrial revolution in Europe and have taken the world by 
storm ever since (cf. Hobsbawm 1962). These powerful intellectual and economic innovations can be summarized as modernity and capitalism, respectively. Modernity's role as a driver has included providing powerful new scientific rationality and cultural individualism that have underpinned the heightened pace of technological and social innovation, while also providing justifications for expansionism, lures for emulation, or foci for rejection (Harvey 1989, Giddens 1990). Capitalism's dynamism comes from the competition for economic resources that defines it. The search for new sources of supply and market opportunity impels, and is driven by, a constant reorganization of the production process (Brenner 1977). Capitalism and modernity overlap in that capitalism builds on the innovations of modernity, while providing the material resources for modernity's spread. The power of globalization in these terms is that even those who have rejected modernity and capitalism must contend with them and, indeed, think and speak in the terms that they have generated.

In terms of the historical experiences of Junagadh District and Banawa Selatan that we analyze in this paper, a key manifestation of modernity has been what Scott (1998) calls "high modernity," in reference to the planned, top-down social and economic development promoted by elites and the state. However, modernity has not been a purely elite exercise, because mass media and other sources have stimulated demand from ordinary people to participate more closely in modernity, particularly through increased consumption of globally produced goods. This links to an extremely important economic stimulus of globalization: mass market capitalism. Much of the economic power of globalization derives from the increasing size of this base (O'Brien and Leichenko 2000), both in terms of the desires of producers for greater production and market share, in order to enjoy greater levels of consumption, and of consumers with rising incomes elsewhere who seek to consume greater amounts of products such as fish, which are exported from the regions we consider. The heightening movement of ideas, goods, and people that constitute globalization generates profound and complex social, economic, environmental, and related changes (Appadurai 1996).

Globalization encompasses an enormous diversity of paths, experiences, and interactions. First, and a topic that we do not pursue here, capitalism and modernity have many and debated forms (Berman 1982). Second, globalization is not a unidirectional or homogenous force, rather, it is shaped by individuals and groups of people with particular interests, interacting in specific places and times (Inda and Rosaldo 2002). Third, and building on this last point, globalization is not a neutral process. As much as globalization is bringing people together, whether through such examples as the now quotidian symbols of mass consumption or through global mass migrations, it is also exacerbating differences. It provides the means for provoking or enflaming intergroup enmities of all kinds, while deepening economic and social inequalities. It brings benefits for some and undermines the quality of life or, even, conditions of life of others (O'Brien and Leichenko 2003).

A valuable way of thinking about the effect of globalization is through the idea of scale, which has the advantage of providing an important bridge between globalization and resilience, because scale is a key term in the social-ecological literature. Gibson et al (2000) use scale to refer to the "spatial, temporal, quantitative, or analytical dimensions used by scientists to measure and study objects and processes." The breadth of this definition is useful, because it signals that scales are constructed by scientists to measure ecological and social phenomena. Cross-scale dynamics are central in the analysis of social and ecological systems, because they direct attention to the diversity of variables and processes involved in the articulation of change and responses to change (Scoones 1999, Peterson 2000). Similarly, globalization, defined by increasing economic integration and cultural interchange, is a cross-scale phenomenon. Studies of globalization necessitate tracing connections across spatial, temporal, and intellectual scales.

Globalization is of particular importance to resilience, because its increasing number of interconnections introduces new variables into human ecosystems and often invokes new forms of social-ecological interactions. These interactions frequently act to undermine the constituent stabilizing structures and processes that determine resilience, at particular times and in particular places. A key obligation of contemporary social science, and one that we feel is particularly relevant to resilience thinking, is to disentangle and critique the effect of globalization in its particular placebased interactions, and to suggest how its diverse effects might be redirected in ways that are more 
socially just, more equitable, and more sustaining of ecological systems. Although globalization tends to erode sustainability, its diversity and contestation offer potential opportunities for efforts and alliances to buffer or move to desirable forms of resilience.

\section{GLOBALIZATION AND RESILIENCE IN TWO COASTAL REGIONS IN SOUTH/ SOUTHEAST ASIA}

As the preceding discussion illustrates, there are important connections between resilience and globalization that deserve greater attention. In examining these connections, we hope to stimulate further insight into those critical structuring variables, i.e., slow and fast variables, that foster social and ecological sustainability. An understanding of change and disruption that combines insights from resilience and globalization may advance analyses of the dynamic relationships between human society and ecological systems. When combined, both concepts may further help to signal when, where, and how coastal societies and ecosystems, such as those described below, are vulnerable, to what extent they are experiencing or have experienced radical shifts, and the implications and prospects for coastal systems and livelihoods.

In keeping with these goals, we use globalization and resilience in the following section to guide our examination of the two case studies in coastal regions of Asia: Junagadh District, Gujarat, India and Banawa Selatan, Central Sulawesi, Indonesia. We do this by identifying: (1) the key variables, $\mathrm{i}$. e., social, institutional, and ecological, that have historically shaped these two coastal areas; these may be considered the crucial slow-moving variables that have stabilized these systems; (2) the processes and forces that have influenced those variables, and importantly, the points at which they intersect to reach thresholds, and at which point these coastal societies and ecosystems have experienced or have begun to experience dramatic change; and (3) the extent to which those forces and processes that are creating dramatic system reconfigurations have fundamentally undermined the resilience of those systems.

\section{Junagadh District, Gujarat, India}

Gujarat State currently has the largest marine fishery of all the Indian states, a position attributable to its long coastline, extensive coastal shelf, and relatively rich breeding grounds for fish. As is typical in tropical waters, it is a multispecies fishery, within which fishers catch dozens of marketable species; the most important are small croakers, shrimp, Bombay duck, ribbonfish, white pomfret, prawns, catfish, Indian threadfin, shark, seer fish, cuttlefish, and squid. Although we refer to the trends in the fishery as a whole, this study focuses on the most important marine fishing area of Gujarat, the coastal belt of Junagadh District (for a more detailed treatment see Johnson 2002). According to the 1997 Census of Fishermen, this area lands $40 \%$ of Gujarat's catch and is home to $15 \%$ of its fishing population (Gujarat 2004). It also hosts the most important craft and gear types in the fishery, including, in order of volume of total catch, trawlers, bag net fishing boats, inboard motor gillnet boats, outboard motor gillnet canoes, and nonmechanized vessels (Gujarat 2000).

The changing patterns of resource use in the fishery of Gujarat state are familiar to those who have studied the trends in global fisheries: from an initial relatively low level of resource extraction, the fishery has gone through a period of rapid growth that began in the late $1950 \mathrm{~s}$, climaxed in the mid 1990 s, and, in recent years, has begun to show strong evidence of a bust. The boom was triggered and fed by a complex series of interactions that constitute the globalization of the fishery. Dominant influences, or fast variables, were the growthoriented policy of the state, fortuitous international economic conditions, and a highly entrepreneurial fishing population. The history of the Gujarat fishery is distinctive, not only for the leading role played by the fishing population in its development, but also because of the failure of all parties involved to build effective institutions for resource management. Consequently, resource degradation has become a critical issue in Gujarat, in particular, for its increasing threat to livelihood security for the state's fishers. An explanation for the failure of the stakeholders in the Gujarat fishery to develop institutions to avoid overfishing needs to consider how the slow variables, that could have sustained the fishery, have been overwhelmed or neglected by the distinctive process of globalization that the fishery has experienced. 
The slow variables on which the fishery rests are the richness and diversity of Gujarat's marine ecosystem and temporal and spatial restrictions on access. Yields for the fishery have been consistently over 550,000 t since 1992-1993, the same years that Gujarat surpassed Kerala to become the largest producer of fish of any Indian state. Unfortunately, the ecology of the Gujarat fishery has not been studied systematically, and there are no comprehensive guides to its functioning. Thus, a formal scientific basis for management of the fishery is largely lacking.

Compared to other tropical and South Asian fisheries, the fishery of Gujarat is relatively underendowed with resource management institutions (Alexander 1977, Johannes 1978, Bavinck 2001, Lobe and Berkes 2004). Nonetheless, there is a category of related slow variables that restricts when and where fishing can be practiced. The temporal restrictions in this group have probably existed as long as fishing has taken place in Gujarat. They consist of prohibitions for Hindu fishers against fishing on certain, particularly, sacred days of the lunar month and a cessation of fishing during the monsoon for all fishers (Johnson 2002). None of these temporal restrictions was associated, until recently, with resource conservation. The religious restrictions were put in place to avoid killing on the holiest days of the month, whereas the monsoon closure was established for safety reasons, because the rough seas during the rainy season are very dangerous, particularly for beach-based craft. Spatial restrictions on fishing have increased as the fishery has become overcrowded. They apply in two areas: first, the stationary bag net fishery of the Navabandar-Jafrabad stretch of coast has a welldeveloped set of institutions for regulating access to the limited number of fishing spots in the area. Second, as the number of craft increased in the best fishing centers elsewhere along the coast, locals began to restrict access to these sites to locally-based craft. In the larger centers of Veraval and Porbandar, restrictions were put in place to lower the congestion of harbor facilities. In the two smaller beach landing centers of Muldwarka and Madhavpur, where restrictions are being discussed, crowding is a factor, but in this case, competition for fish is also important. However, as with the temporal restrictions on fishing, fishers do not mention ecological concerns as reasons for the spatial restrictions on access.
An important question for the Gujarat fishery is why an indigenous system explicitly for resource management has not been developed. A major part of the answer to this question lies in the fast variables, mentioned above, that are associated with globalization. However, two other contextual elements are important in explaining that management failure. The first of these was the paradoxical effect of the sheer richness of the fishery, in terms of species diversity and total biomass. These characteristics likely provide an important basis for ecological resilience in the fishery, but they also provide a powerful stimulus for increasing fishing effort without concern for its restriction, because the fishery seemed capable of matching increasing fishing effort with increasing total catch until the 1997-1998 season. However, in hindsight, many older fishers reported that there were signs of concern from as early as the mid-1980s when they had first noticed declines in their catches of the primary target species of pomfret and prawns. The second contextual element, which may explain the lack of resource management institutions, is the broader culture of Gujarat in which the fishery is embedded. Gujarat's majority Hindu community is well-known in India for its staunch vegetarianism, which is based on the idea of ahimsa, that the taking of life is sinful. Proscriptions on fishing on certain days of the month are evidence of the influence of this cultural context. Curiously, the Gujarat's Hindus vegetarian ethic has not been translated into ecological activism in relation to marine ecological conservation. This may be related to the highly stigmatized nature of fishing, which makes many Gujarati Hindus little inclined to engage with it. One also gets a sense in Gujarat that the coast is beyond the consciousness of most Gujaratis. The coasts are largely ignored as pleasure destinations, and development of the seaboard is largely industrial.

Globalization of the Gujarat fishery has been shaped by this distinctive cultural context. First, the lack of a significant market in the immediate hinterland meant that the fishery was export based even in the early days of its development in the 1950s. Second, it meant that until at least the 1970s the fishery of present day Gujarat was relatively underexploited compared to the other coastal areas in India (see Johnson 2002). Third, it gave a great deal of autonomy to fisher groups, and particularly caste organizations, to develop the fishery as they saw fit. Unfortunately, neither they nor the state agencies were concerned about resource management until recently. 
In the early years of fishery development in Gujarat, during the 1950s and 1960s, the state was the key agent for fishery development. With assistance from the American Technical Cooperation Mission and the Food and Agricultural Organization (FAO), the state's strategy was a comprehensive attempt to modernize all types of vessels and gear in Gujarat's fishery. This included the small-scale sector, in which outboard engines and nylon nets were introduced, along with much more efficient trawler technology. State intervention was stimulated, initially, by a desire to increase protein supplies for the Indian poor, but by the beginning of the 1960s, with the dawning realization that prawns had a high earning potential on the foreign market, export opportunities increasingly became the impetus for fisheries development. By the late 1960s, a first threshold in the Gujarat fishery was crossed with the acceptance of trawling by the dominant Kharva fishing caste in the main ports of Veraval and Porbandar. This lay the foundation for the reorganization of the fishery around new species, the indigenization of fish processing, and the spread of wage- and labour-based relations of production in the fishery.

Throughout the 1970s and early 1980s, the Gujarat fishery grew steadily but undramatically. The key changes during these years were the rise of trawling to preeminence in terms of the proportion of total catch and landed value, the establishment of locallybased processing capacity, and the increasing power of local fishers in the growing industry. Although fish processing has been partially controlled by nonlocal interests, Gujarati fishers have been largely able to maintain control over local fish supply networks and the ownership of fishing craft, but much of the fishing on trawler boats has increasingly been done by migrant laborers. Nonlocal fishing boats have plied Gujarat's waters, and the operations of some, especially foreign joint venture boats, have provoked local anger. In recent years, these boats have not been permitted to land at Gujarat ports. The successful modernization of these years also meant that the state was displaced from its leadership role by increasingly confident fishers.

In the late 1980s, the Gujarat fishery became truly globalized with the commencement of large-scale exports to China. The Chinese were eager to purchase a wide range of species that had previously been largely ignored, sold locally, or sold for fish meal. Prices increased quickly, creating the basis for an unprecedented export-induced economic boom in the fishery. One indication of that growth is trawler numbers, which grew from 2522 in 1988-1989 to 6390 in 1997-1998 (Gujarat 2000). The number of processors and other industrial units associated with the fishery grew very rapidly over the same period. However, the boom rather rapidly proved to be unsustainable. Gujarat's fishery crossed a second major threshold into an era of economic and ecological crisis in 1997. The trigger was the Asian economic crisis of that year. The regional economic upheaval triggered a slump in demand for fish and a corresponding decline in prices. The economic malaise also brought attention to an underlying ecological crisis. Steadily increasing fish prices throughout the 1990s had permitted an increasing effort, in the form a rapidly growing fishing fleet and longer trips and in order to sustain catches, clear signs that fish stocks were under too much pressure. These indications were corroborated by growing fisher concerns about their declining catches. Fishers pointed to a worrying trend of serial overfishing (cf. Pauly et al. 1998): the first species demanded by the international market, prawns, lobster, and pomfret, had declined in availability since the 1980s. By the late 1990s, the various species now saleable on the Chinese market were also declining in availability.

The crisis in the Gujarat fishery has continued to the present. In Junagadh, a large proportion of the trawler fleet can only afford to fish during the most productive three to four months of the fishing season. Participants in the fishery observe that wealthy fish processors and suppliers are taking advantage of this situation to buy up vessels from those who cannot afford to keep their boats running. These points indicate that the most capital-intensive and globalized sector of the fishery is in the process of restructuring; this has implications for the total employment and wealth generating potential of the fishery as a whole.

Although the fishers of Gujarat are extremely concerned about the state of the fishery, there is little evidence that they have overcome their internal differences and succeeded in building institutions for fisheries management. Indeed, although the measures for spatial control over fishing seem to be strengthening, temporal restrictions on fishing have been under pressure. Observance of religious fishing closures is weakening, particularly among trawler fishers, who have abandoned them, and fishing during the monsoon has become a widely 
recognized ecological problem for the fishery. Nonetheless, the current crisis is also a significant moment of opportunity, because the stakeholders in Gujarat's fishery generally acknowledge that the current lack of an institutional system for the management of the fishery is untenable.

There are at least three hopeful signs for the future of the fishery. The first of these is that the smallscale gillnet sector that could provide a model for a more sustainable, community-based, and employmentgenerating fishery seems to be surviving the current crisis better than the trawler sector. Second, for the first time in the history of the fishery, an outside NGO, Protsahan, has taken an active role as catalyst, pushing Gujarat fishers to meet with one another and with state organizations to develop management institutions. Third, the crisis of the fishery gave the Gujarat State Department of Fisheries sufficient justification to have the Gujarat State Fisheries Act passed. The Act contains provisions that could provide a legal foundation for a more ecologically sustainable fishery. Whether such a fishery can be constructed depends upon the ability of the fishers of Gujarat to overcome their numerous caste, class, and religious divisions, and to establish institutions that will sustain fishing in this rich marine ecosystem, which if not pushed too hard, will rebound.

\section{Banawa Selatan, Central Sulawesi, Indonesia}

The coastal portion of Banawa Selatan in the Donggala region, Central Sulawesi has historically provided local people with an opportunity to harvest, for market or consumption, a range of coastal, nearshore, and deepwater marine resources, including multiple species of fish, crab, shrimp, and numerous other products, e.g., building materials, firewood, parts for boats, dyes for fishing gear (PSL/ UNTAD 2000, Armitage 2002). The supplies of these valuable resources were related principally to the existence of the intact mangrove forest ecosystems that have fringed much of the coastline in Banawa Selatan. However, over the past several decades, socio-cultural changes and intense economic development have significantly altered local livelihoods and resource harvesting practices, and have led to a corresponding transformation of the coastal system.

Originally an area of Kaili people, the coastal region of Banawa is now inhabited by a diversity of ethnic groups, including Buginese, Mandarese, Sundanese, and Javanese. Moreover, the population of the region has increased by $10 \%$ over the past decade, a result of national transmigration policies, settlement schemes, and the promotion of new economic activities in the region (PSL/UNTAD 2000). Such elements of change have set the stage for the rapid and fundamental processes of coastal resource degradation that are familiar to observers of coastal transformations in many other areas of Indonesia and Southeast Asia. Moreover, these processes of change can be related to several critical variables and stages of social-ecological disruption that have linked new forms of coastal resource appropriation and increasingly globalized markets and modes of economic production.

The most obvious source of disruption in the region has been the rapid conversion of the intact mangrove ecosystems to aquaculture ponds, a process that has significantly changed a critical structuring variable, i.e., a slow variable, in the coastal system. Over the past $15 \mathrm{yr}$, in particular, a semi-intensive brackish water aquaculture production system has emerged in the coastal region of Banawa, the major products of which include milkfish (Chanos chanos), along with a number of other outputs, e.g., tiger prawn (Panaeus monodon) and banana prawn ( $P$. merguiensis). However, this transformation has come at a significant cost. The extent of mangrove forest loss in the Banawa Selatan region between 1985 and 2000 is estimated at approximately $69 \%$ (Armitage 2002). The implications of this dramatic conversion of the mangrove forest ecosystem to aquaculture schemes are significant and include habitat and species loss, declines in the coastal capture fishery, water quality impacts associated with aquaculture, i.e., agro-chemical pollution, socio-cultural conflict, and the economic marginalization of coastal communities. Concerned with the protein requirements of a growing population and a desire for foreign exchange, the provincial fishery department is nevertheless encouraging additional aquaculture development, and has projected a $10 \%$ increase in aquaculture production in its 2001-2005 strategic plan (PERIKANAN 2000). However, most striking is the role of recent migrants and external entrepreneurs in facilitating the removal of ecologically and socio-economically valuable mangrove forest ecosystem to support the development of brackish-water aquaculture initiatives. 
Although the transformation of mangrove forests to brackish water aquaculture ponds is the most obvious illustration of social-ecological change in the Banawa Selatan region, there are other critical structuring variables that have been reshaped by the forces of globalized markets and changing patterns of economic production, such as property rights, community norms, and associated collective action values. Thus, to understand the dynamics and implications of coastal transformation in the region, it is helpful to explore the relationships between market forces, ethnicity, and property rights, the tacit approval of nonsustainable resource appropriation fostered by administrative and legal regimes at local to national scales, and the underlying policy narratives that have supported mangrove forest conversion. Although by no means the only suitable starting point, an analysis of property rights offers a useful entrée to examine the dynamics of coastal resource appropriation in the Banawa region, because it reveals a fundamental change to a critical slow variable that has stabilized social-ecological conditions in the region.

Before the wide-scale clearance of mangrove forests, a common property resource regime was administered by traditional leaders and supported through customary law, i.e., hukum adat. However, the "open access" mangrove ecosystem proved an easy target for conversion to alternative resourcebased systems by extralocal interests, unaware or uninterested in customary systems of resource tenure. A resource regime, once used by a crosssection of community interests to harvest a diverse range of products associated with intact mangrove ecosystems, (see Whitten et al. 1987, Soendjoto and Arifin 1999, Armitage 2002) has in the last 15-20 yr been increasingly privatized, and commodities have been concentrated among a relatively small number of elite. The five individuals who control much of the aquaculture pond in Tolongano, a village in Banawa Selatan, are district government officials or wealthy entrepreneurs from outside the region. Nearby in the village of Lalombi, two individuals from the regional capital, Palu, own a majority of the aquaculture ponds, i.e., approximately 50 ha each. Although valuable commons resources and resource management systems continue to be degraded in the region, efforts to constrain aquaculture development have proven ineffective.

The reasons for the resource degradation in Banawa Selatan are complex, but a number of fast variables have coalesced to destabilize property rights and reinforce social and ecological change. For example, critical variables contributing to the failure to constrain mangrove forest conversion are the increasing ideological and legal strengths of private property rights in the Indonesian context. Moreover, nested within the private property rights discourse in Indonesia is a bureaucracy in need of cash and lacking the political mandate required to foster sustainable resource use. As Lowe (2000) illustrated, bureaucracies in Indonesia are required to secure much of their own operating budget, and in this context, the income associated with permitting and licensing activities are important enterprises. It is in the self-interest of government staff to grant permits for activities such as aquaculture development and forest concessions, rather than restrict access to common property regimes. At the same time, a lack of clarity surrounds the ownership of aquaculture ponds, both in terms of the process for obtaining ownership and in identifying those who can produce the required permits (see Supriadi 1999). However, this inconsistency is advantageous for a bureaucracy that can charge "informal fees" when possible, while generating formal revenue from the permitting process as required. Local communities, unskilled and unfamiliar with the nuances of the bureaucratic process, perceive themselves as having limited power to seek redress under these circumstances.

The outcomes of this property rights transition and administrative uncertainty are embedded in a further set of economic dynamics. Specifically, the products of aquaculture production typically have both domestic and international market destinations. Milkfish are destined for local and/or domestic markets, whereas prawns may be bound for more lucrative export markets. Although the consumption of aquaculture products in distant locations serves the process of consumption-production disassociation, which is increasingly common in this era of intensive, mechanized grain and protein output, the intricate social and ecological consequences of production are not so easily avoided in Banawa Selatan. The globalized nature of aquaculture production is consistent with Indonesia's adoption of neo-liberal economic policies and efforts to address debt repayment concerns (GOI/IMF 2000), but subsistence fishers and coastal farmers, historically dependent upon the products of commons resources and ecological systems, experience the direct livelihood impacts. 
Compounding the economically-scaled process of coastal resource appropriation and transformation in the Banawa region are ethnic differences associated with the control and production of aquaculture developments. A focus on ethnic change and migration reveals a further historical stabilizing variable articulated as prevailing norms and values regarding the coastal system and the conditions that support collective choice arrangements. With the process of ethnic change in Banawa Selatan, more heterogeneous norms and values have emerged and become sources of conflict. For example, in the Banawa region, local perceptions that Indonesians of Chinese descent control significant amounts of aquaculture are only partially accurate. In actuality, the large-scale aquaculture entrepreneurs in the region and the individuals they employ to manage the ponds come from both the Chinese community and the Buginese ethnic community, whose roots are in southern Sulawesi. Those individual community members, who own smaller areas of aquaculture pond, are typically Bugis and/or local government officials. The indigenous Kaili rarely participate in aquaculture production, serving primarily as laborers involved in the initial construction of the ponds. Therefore, ethnic hierarchies and scales associated with aquaculture production are well-entrenched in the Banawa region, and they influence the distribution of costs and benefits of coastal resource transformation.

The processes of mangrove forest conversion and aquaculture development are situated in an array of variables that have coalesced to transform the coastal region of Banawa over a relatively short time. As outlined above, these factors include: a desire for additional sources of domestically produced protein, requirements for foreign exchange, an ideological bias towards private property rights regimes, administrative and legal frameworks that further undermine local property rights and the ability of communities to withstand the forces of more powerful interests, and variations in the control of the aquaculture development and production processes that are compounded by ethnic hierarchies. However, more fundamentally, this complex milieu of interactions is predicated upon a foundational narrative that provides the "incontrovertible logic" for the ongoing development of aquaculture ponds in the Banawa region and elsewhere in Indonesia. Specifically, the supporting policy narrative rests upon a tripartite set of assumptions that: (1) local resource-use systems are economically inefficient, (2) aquaculture development and other forms of intensified resource appropriation provide needed social and economic benefits to society, and (3) those socio-economic benefits will be appropriately distributed.

\section{DISCUSSION}

Both of the regions presented in these two case studies have experienced significant, and at certain points, rapid periods of change and transformation. Moreover, current conditions in both regions can be linked to the influence of modernity and capitalism. However, the manner in which the forces of globalization have coalesced in each region is distinct in some important respects. Therefore, using key concepts of resilience, we can compare our case studies and examine the variables that initially acted to stabilize Junagadh District (Table 1) and Banawa Selatan (Table 2) into particular patterns, the emergence of those faster variables that have come together to create increasingly unstable social, economic, and ecological conditions, and the potential impacts of the interactions among these slow and fast variables. Both tables reduce considerable historical complexity by focusing on the interaction effects between key slow and fast variables that appear to have been dominant in the history of the two areas. Although the flow of the narratives in the tables is from left to right, there are also considerable up-down and side-to-side interactions that we have touched on in this paper.

The most important difference between the two cases, in terms of stabilizing variables, is in the area of property rights. In Banawa Selatan, property rights were defined as part of a locally-based system that regulates the use of the mangrove ecosystem. Apparently, this system was historically effective in maintaining a steady but sustainable withdrawal of natural resources from the mangrove ecosystem. In the case of coastal Junagadh, access to marine fishing was restricted by cultural stigmas against killing fish, which left the fishery to economically or socially marginal groups, and was the source for closure of fishing on certain days. Arrangements closest to a property rights system are evident only in the spatially-restricted bag net fishery, and to an extent, in the growing restrictions on access to some fishing ports. A second difference between the two areas lies in the different ways in which integration with the international markets has proceeded. 
Table 2. Globalization and resilience in Banawa Selatan, Central Sulawesi.

\begin{tabular}{ll}
\hline \hline Slow variables & $\begin{array}{l}\text { Principal fast variables acting on } \\
\text { slow variables }\end{array}$
\end{tabular}

Property rights

Community norms and collective choice arrangements

Intact mangrove ecosystem
- Ideological and value change, i.e., shift to privatization over common property

- Desire to earn foreign exchange through resource intensification strategies

- Ethnic change, i.e., migrants

- Associated ideological change, values towards privatized property rights

- Desire for domestic protein obtained through transformation of the ecological system, i.e., to aquaculture

- Loss of mangrove ecosystem leading to alternative economic needs, i.e., increased aquaculture, more pressure on capture fisheries
- Increased marginalization, decreased stability in livelihoods

- Emergence of resource-based conflict

- Weakened connection between environment and livelihoods

- Centralization of income distribution

- Increased resource dependency, i.e., limited set of naturally occurring resources

- Increased marginalization, decreased stability in livelihoods

- Decrease of ecological regenerative capacity, i.e., increased hazards, coastal erosion/flooding, water quality and biodiversity loss
Fishers in Junagadh have retained and indeed consolidated a position of dominance, whereas many of the traditional inhabitants of Banawa Selatan have been pushed into a subordinate position by outsiders, e.g., historical and recent migrants, and thus have lost control of the coastal mangrove areas that they once regularly accessed. However, in neither case, did groups within the changing social organization of production develop new institutions for conservation. Therefore, ecological systems in both places are under serious threat. The outlook would seem most hopeful in Gujarat where at least local groups, that might be most logically expected to have interest in long-term sustainability, remain in control.

A comparison of these two cases reveals the benefits of linking globalization more explicitly to the 
Table 1. Globalization and resilience in Junagadh District, Gujarat.

\begin{tabular}{ll}
\hline \hline Slow variables & $\begin{array}{l}\text { Principal fast variables acting on } \\
\text { slow variables }\end{array}$
\end{tabular}

Rich and diverse marine ecosystem

Temporal and spatial restrictions on access to the fishery
- $\quad$ State policy emphasizing modernization to increase production

- Rapid growth in international demand for fish products

- Entrepreneurial fishing population

- State policy emphasizing modernization to increase production

- Rapid growth in international demand for fish products

- Entrepreneurial fishing population
- Substantial wealth creation

- Increasing importance of and dependence on the international export market

but

- Growing evidence of ecological crisis: declining catches and serial overfishing

- Increasing economic and livelihood insecurity

- Local retention of control over the fishery and increasingly destructive competition for coastal resources among fishers has eroded internal access restrictions and led to local-level, open-access crisis resilience discourse. The rapid changes brought about by globalization in Junagadh and Banawa Selatan present serious challenges to the resilience of these social-ecological systems. In the Sulawesi case, the slow variables that have historically structured this social-ecological system, e.g., property rights, intact mangrove forests, ethnic homogeneity, and shared norms, have been transformed. A new human ecosystem has formed that is more socially complex, but its coastal resources have been degraded and social injustice is a concern. In the Junagadh case, temporal and spatial access restrictions have persisted, but their lack of integration into a larger, explicit resource management system or, indeed, resource conservation ethic means that they have not prevented the serious depletion of marine resources. Perversely, all that has been resilient in Gujarat are conditions exacerbating the open-access tragedy that seems to have settled on the fishery. Hopefully, this is just the drawn-out destruction phase of the adaptive cycle, with the new Fisheries Act being a key element in a reorganization phase.

The two histories that we have traced raise a number of questions for us about resilience. Where, in such dynamic, globalizing situations should resilience be located? What is the appropriate scale or scales at which to assess resilience? Should a specified original resilient state of the human ecosystem, now completely transformed, still be considered an ideal? Alternatively, should we aim for a more a 
general set of management goals based on the idea of resilience that recognizes current social, economic, and ecological realities? We address these questions by examining the complementarity and the tensions between resilience and globalization. Our first approach to the task is to reflect on the epistemological challenge of linking the two concepts. We pursue this by asking whether globalization unsettles the distinction between the slow and fast variables that underpin resilience.

\section{The epistemological challenge of linking resilience and globalization}

An attempt to reconcile resilience and globalization has to engage with their divergent origins, those of the former in the ecological sciences and those of the latter in the social sciences. These different traditions raise the possibility of an epistemological gap or, at least, significant differences in assumptions. They also raise a warning flag about the difficulties of linking human society with ecological systems. There are significant differences in the way in which the two systems operate, and differences in the way that scientists construct them that require careful analysis as an integral part of understanding their ongoing interactions (Stepp et al. 2003). Rather than attempting a comprehensive treatment of the epistemological questions here, we suggest some preliminary ideas and point to epistemology as an important and relevant area of work.

Epistemology is concerned with the nature of knowledge. As the origins of resilience thinking demonstrate, divergent understandings of knowledge are held and debated within the natural and social sciences. The emergence of complex systems approaches from the natural sciences is a reevaluation of the idea that science can generate certain knowledge about reality. Resilience, itself, stems from a reassessment of the idea that ecological science can generate certain knowledge about ecosystems. However, it is recognized that knowledge of ecosystems can only be incomplete, and that changes can generate unpredictable results. This shift to an epistemology that recognizes uncertainty as a central attribute of coupled socialecological systems parallels the much more radical postmodern turn within the humanities and social sciences, which, in its most extreme forms, undermined the basis for any claims of representation or causality. Although the high tide of postmodernism has passed, it has stimulated an epistemological shift within the social sciences toward an increased acceptance of indeterminacy. A similar movement within the natural and social sciences toward an increasing acceptance of uncertainty indicates a potential epistemological meeting ground for the reconciling of globalization with resilience. However, some challenges remain.

From the perspective of social science, two obstacles have to be overcome before resilience can be integrated into the analysis of the distinct dynamics of human societies. The first of these is a problem of historical baggage related to the use of the term system to describe human society. Anthropology and sociology have important legacies of engagement with system as a conceptual tool for describing society. Systems thinking peaked with the popularity of structural functionalism in the 1950 s and 1960s. The image of society using this approach was one of a discrete and complete unit that resembled a biological organism or an autonomous ecological system (Scoones 1999). From the 1970s onwards, structural functionalism was subject to vigorous critiques of its basic presumptions about the order of human social life. These have left a strong legacy of resistance to societies as systems and the equation of society with nature. As has been pointed out elsewhere (Scoones 1999, Abel and Stepp 2003), even if the "new ecology" is based on a completely different understanding of systems, anthropologists and sociologists will take a good deal of convincing before they will open up to complex adaptive systems thinking.

One of the most important shortcomings of the structural functional view of society as a closed, functional system is that it suffocates the possibility of human agency. The second concern with resilience continues along this theme. In order for resilience to link social and ecological systems in a way that is convincing for social scientists, it has to recognize the distinctiveness of human systems. The functioning of human society is distinct from that of natural systems, because among the Earth's organisms, humans are unique in the degree of their sentience. The ability of humans to learn by reflecting on their actions, and modifying them as a result, means that as a species, humans have levels of cultural complexity, diversity, and dynamism similar to those of entire ecosystems. Human diversity serves as a basis for intergroup competition, collaborations, and hierarchies that 
shift quickly. This is a complex system of sorts, with the distinction that its self-organizing capabilities are partially conscious and reflexive. In a situation of competing interests, and explicit self-interests, the key question for resilience is, to paraphrase Amartya Sen (1992), resilience of what, for what purpose, and for whom (see also Carpenter et al. 2001)? For resilience to be useful in assessing social institutions and in marking roads to sustainability and social justice, it has to be situated in the context of complex, contested, and changing human interests, and the uncertainty of the outcomes of human interactions.

The importance of situating resilience within the constellation of local human interests is brought out clearly in the two case studies presented in this paper. In Banawa Selatan, immigrants and the local Kaili compete for resources in the context of broader state interests that favor certain trajectories of development and thus certain groups. In coastal Gujarat, the fishery is split between many competing groups, e.g., small-scale fishers, trawler fishers, export processors and traders, women petty fish dealers, producers for the domestic salt fish market, and numerous caste and religious associations. How do we balance these divergent interests and the interest of ecological sustainability to define the ideal resilient system? In summary, resilience thinking requires further reflection on, and engagement with, its foundational assumptions as it engages more fully with social science, if it is to be widely accepted as a conceptual tool to guide research and practice.

\section{The conceptual challenge of globalization to resilience}

What do the two case studies of globalization examined in this paper reveal about the prospects for resilience? Given the magnitude and speed of social-ecological change experienced in these two regions, is resilience a feasible management objective? Folke et al. (2002:19) have suggested that whether complex social-ecological systems will remain in a desirable state has much to do with the "slowly-changing variables that determine the boundaries beyond which disturbances may push the system into another state." In the case of coastal Junagadh District in Gujarat (Table 1), the slowlychanging variables have been the relatively unknown ecosystem basis of the fishery and temporal and spatial restrictions on fishing that are embedded in Gujarat's distinctive cultural context. In the Banawa example (Table 2), the slowlychanging variables include property rights, collective norms as a by-product of ethnic homogeneity, and the biomass of intact mangrove ecosystems. Such "stabilizing" and slowlychanging variables are consistent with the classes of variables identified in other contexts, including land use, nutrient stocks, land tenure, and policy (Folke et al. 2002).

Identification of these critical slow variables is important, because they are an essential source of resilience and represent the accumulated experience and memory necessary for reorganization following disturbance (see Folke et al. 2002, Gunderson and Holling 2002). However, globalization presents a challenge to the idea of slow-moving variables. The intensity and pace of change catalyzed by modernity and capitalism call into question whether these slow-moving and stabilizing variables, historically associated with the coastal systems examined in this paper, can continue to exist in a meaningful form. The dramatic effect of globalization in the two coastal regions serves to remind us that the ability of many social-ecological systems to maintain resilience is doubtful. Degraded coastal systems in many parts of the world no longer contain the "experience" and "diversity of [positive] options" (sensu Folke et al. 2002) needed for renewal, reorganization, and resilience in the face of disturbance. Therefore, as a framework that complements resilience analysis, a better understanding of the effect of globalization in particular places may help reveal when and how to anticipate thresholds of change. However, the scale and speed of globalization may also illustrate how the very notion of a threshold is itself problematic, because the variables that can coalesce to flip a system from one state to the next appear to occur with increasingly regularity. What does this mean for resilience analysis?

First, if the effects of globalization are to be better incorporated into resilience analysis, further testing of resilience ideas using socio-political, institutional, and economic frames of reference will be helpful. In this regard, there have been a number of contributions to resilience analysis (Adger 2000, Peterson 2000, Carpenter et al. 2001, Walker et al. 2002), but more effort is required to draw attention to the relationships among socio-political and institutional change, and economic globalization and resilience. The role of scale and its construction 
are particularly important. Specifically, globalization enhances or exacerbates the intensity of cross-scale interactions, and at local scales, it is increasingly difficult to identify the slow-moving variables that contribute to positive social-ecological resilience. However, if we scale-up, we can identify the capitalist system of international trade and organization as a resilient one. There are many fastmoving variables associated with this system, e.g., commodity flows, derivatives trading, that can create local-regional instabilities, but the system itself has become remarkably resilient. Thus, the loss of resilience at local scales is a function of the resilience of the global capitalist market system.

Second, an argument has been made about the need for indicators to monitor "...key variables and [which] aim to manage diversity for insurance to cope with uncertainty" (Folke et al. 2002:24). An explicit recognition of globalization can help to focus this search for early-warning signals, such as changes to property rights or key cultural transformations that may destabilize socialecological systems. As already noted, the two case studies examined in this paper illustrate a number of early-warning signals and destabilizing variables. However, the challenge is to identify these early-warning signals before they coalesce and undermine the forms of resilience that contribute to sustainability. Finally, although the metaphorical utility of resilience is attractive, and the identification of slow and fast variables useful in understanding coupled social-ecological systems, the forces of change created by globalization blur that distinction in many ways. A much better empirical understanding of the contingent relationship among slow and fast variables in the context of globalization is necessary if insights of value are to be generated.

\section{CONCLUSIONS}

"Resilience-building policy attempts to increase the range of surprises with which a socio-economic system can cope. It also conserves and nurtures diversity - of species, of human opportunity, of learning institutions and of economic options - that is necessary to renew, reorganize and adapt to unexpected and transformative circumstances" (Folke et al. 2002:24).

As illustrated by the cases of coastal Junagadh District, India, and Banawa Selatan, Indonesia, globalization dramatically intensifies socioeconomic and ecological change. The key indicator of that change is the heightening of cross-scale interactions. These changes are provoked by increasing interactions with far-flung and global markets and with modern ideas and ideals of development and science. The net effect of the globalization process is to heighten uncertainty and surprise, because local-scale interactions become increasingly linked to processes and forces at broader scales. The diversity of ideas, institutions, and opportunities that influence different local scales may vary, but that diversity, when created through the process of globalization, may come at the expense of locally-grounded slow variables that include institutions for memory and learning, and may reduce opportunities that favor local social and ecological resilience. The negative consequences of globalization for resilience are shown in our two case studies. In Junagadh, the rich ecological base and sparse but promising local restrictions on access failed to foster resilience, because the external drivers of fishing intensification were sufficiently powerful for the fishing population itself to push the fishery into overexploitation. In Banawa, local property rights and access institutions were rapidly undermined, at the expense of mangrove ecosystem resilience, by powerful outside entrants to the area supported by a strong legitimating ideology.

Two major, but general, implications for resiliencefocused policy arise from our analysis. First, although local-level resilience may remain the objective, action to promote resilience has to operate at multiple scales. Social and ecological resilience depends on making cross-scale institutional connections reflecting the multiple levels of interaction that characterize globalization. This means that resilience action has to build cross-scale intelligence and alliances to anticipate, and even occasionally, preempt unsettling surprises. As noted, the capacity of system actors to do that actually depends, in large part, on whether earlywarning indicators of destabilizing change can be identified. This is no easy task given the speed and intensity of globalization's influences. Second, resilience has to be carefully located, a task that is complicated by its normative aspects. For what and for whom are we trying to promote resilience? For the outside entrants into aquaculture in Banawa, their ecologically destructive activities may be an important part of an economic strategy to preserve the resilience of their socio-economic status. This economic strategy, from their perspective, is rooted 
in a fundamental and legitimate rationality, but from the perspective of the ecosystem and historical resource users, it is one that is disruptive and destructive. Viewed through the lens of globalization, resilience for what and for whom is thus about trade-offs, potential conflict, and difficult socio-political and institutional choices (cf. Bailey and Jentoft 1990). For policy makers and other outsiders interested in promoting broad social, economic, and ecological resilience, hard choices are inevitable and consequential. It behooves them to ground such choices in the best possible interdisciplinary methodologies for understanding local settings and their cross-scale connections.

Responses to this article can be read online at: http://www.ecologyandsociety.org/voll1/iss 1/art2/responses/

\section{Acknowledgments:}

The research findings on the fishery of Gujarat were made possible through SSHRC Doctoral and Postdoctoral Fellowships, an IDRC Doctoral Research Fellowship, and funding from the Indo-Dutch Program for Alternatives in Development project 5.2.110. Findings on coastal change in Banawa Selatan were made possible with the support of an IDRC Doctoral Research Fellowship, as well as the Canadian International Development Agency (through the University Consortium on the Environment Project, a sub-contractor for the Collaborative Environmental Program in Indonesia). We also wish to thank Dr. Fikret Berkes for travel grants (provided through the SSHRC-supported Integrated Management Node of the Oceans Management Research Network) to attend the Environmental Studies Association of Canada meetings in 2004 at which a version of this paper was presented. Finally, we thank the two anonymous reviewers and Doug Clark for their helpful comments and suggestions on ways to improve the paper.

\section{LITERATURE CITED}

Abel, T., and J. R. Stepp. 2003. A new ecosystems ecology for anthropology. Conservation Ecology 7 (3):12. [online] URL: http://www.consecol.org/vol7/iss3/art12.

Adger, W. N. 2000. Social and ecological resilience: are they related? Progress in Human Geography 24 (3):347-364.

Anderies, J. M., Janssen, M. A., and E. Ostrom. 2004. A framework to analyze the robustness of social-ecological systems from an institutional perspective. Ecology and Society 9(1):18. [online] URL:

www.ecologyandsociety.org/vol9/iss1/art18.

Appadurai, A. 1996. Modernity at large: cultural dimensions of globalization. University of Minnesota Press, Minneapolis, Minnesota, USA.

Armitage, D. R. 2002. Socio-institutional dynamics and the political ecology of mangrove forest conservation in Central Sulawesi, Indonesia. Global Environmental Change 12(3):203-217.

Bailey, C., and S. Jentoft. 1990. Hard choices in fisheries development. Marine Policy 14(4):333-344.

Bavinck, M. 2001. Marine resource management: conflict and regulation in the fisheries of the Coromandel coast. Sage, New Delhi, India.

Berkes, F., and C. Folke, editors. 1998. Linking social and ecological systems: management practices and social mechanisms for building resilience. Cambridge University Press, Cambridge, UK.

Berkes, F., C. Folke, and J. Colding, editors. 2003. Navigating social-ecological systems: building resilience for complexity and change. Cambridge University Press, Cambridge, UK.

Berman, M. 1988 [1982]. All that is solid melts into air: the experience of modernity. Penguin Books, New York, New York, USA.

Brenner, R. 1977. The origins of capitalist development: a critique of neo-Smithian Marxism. New Left Review 104:25-92.

Carpenter, S., B. Walker, J. M. Anderies, and N. 
Abel. 2001. From metaphor to measurement: resilience of what to what? Ecosystems 4:765-781.

Food and Agriculture Organization of the United Nations (FAO). 2005. Review of the state of world marine fishery resources. FAO Fisheries Technical Paper 457. Fishery Resources Division. Rome, Maine, USA.

Folke, C., S. Carpenter, T. Elmqvist, L. Gunderson, C. S. Holling, B. Walker, J. Bengtsson, F. Berkes, J. Colding, K. Danell, M. Falkenmark, L. Gordon, R. Kasperson, N. Kautsky, A. Kinzig, S. Levin, K. Goran-Mäler, F. Moberg, L. Ohlsson, O. Olsson, E. Ostrom, W. Reid, J. Rockström, H. Savenjie, and U. Svedin. 2002. Resilience and sustainable development: building adaptive capacity in a world of transformations. Scientific background paper for the World Summit on Sustainable Development. The International Council for Scientific Union, Stockholm, Sweden. [online] URL:

www.unisdr.org/eng/risk-reduction/wssd/rd-wssd-eng. $\underline{\mathrm{htm}}$.

Gibson, C. C., E. Ostrom, and T. K. Ahn. 2000. The concept of scale and the human dimensions of global change: a survey. Ecological Economics 32:217-239.

Giddens, A. 1990. The consequences of modernity. Stanford University Press, Stanford, California, USA.

Government of Indonesia and the International Monetary Fund (GOI/IMF). 2000. Letter of intent and memorandum of understanding between the government of Indonesia and the International Monetary Fund. Jakarata, Indonesia.

Department of Fisheries, Government of Gujarat (Gujarat). 2000. Gujarat fisheries statistics 1999-2000 Gandhinagar, Gujarat, India.

Department of Fisheries, Government of Gujarat (Gujarat). 2004. Gujarat Fisheries Statistics 2002-2003. Gandhinagar, Gujarat, India.

Gunderson, L. H. 2003. Adaptive dancing: interactions between social resilience and ecological crises. Pages 33-52 in Berkes, F., C. Folke, and J. Colding, editors. Navigating socialecological systems: building resilience for complexity and change. Cambridge University
Press, Cambridge, UK.

Gunderson, L. H., and C. S. Holling, editors. 2002. Panarchy: understanding transformations in human and natural systems. Island Press, Washington, D.C., USA.

Harvey, D. 1989. The condition of postmodernity: an enquiry into the origins of cultural change. Basil Blackwell, Oxford, UK.

Held, D., and A. G. McGrew, editors. 2003. The global transformations reader: an introduction to the globalization debate. Polity Press, Cambridge, UK.

Hobsbawm, E. 1962. The age of revolution: 1789-1848. Weidenfeld and Nicholson, London, UK.

Holling, C. S. 1973. Resilience and stability of ecological systems. Annual Review of Ecology and Systematics 4:1-23.

Holling, C. S. 2001. Understanding the complexity of economic, ecological, and social systems. Ecosystems 4:390-405.

Holling, C. S., and G. K. Meffe. 1996. Command and control and the pathology of natural resource management. Conservation Biology 10:328-337.

Inda, J. X., and R. Rosaldo. 2002. Introduction: a world in motion. Pages 1-36 in X. Inda and R. Rosaldo, editors. The anthropology of globalization: a reader. Blackwell Publishing, Oxford, UK.

Johannes, R. E. 1978. Traditional marine conservation methods in Oceania and their demise. Annual Review of Ecology and Systematics 17:305-306.

Johnson, D. 2002. Emptying the sea of wealth: globalisation and the Gujurat Fishery, 1950-1999 (India). Dissertation. University of Guelph, Guelph, Ontario, Canada.

Lobe, K., and F. Berkes. 2004. The padu system of community-based fisheries management: change and local institutional innovation in south India. Marine Policy 28:271-281.

Lowe, C. 2000. Global markets, local injustice in southeast Asian seas: the live fish trade and local 
fishers in the Togean Islands of Sulawesi. Pages 234-258 in C. Zerner, editor. People, plants, and justice: the politics of nature conservation. Columbia University Press, New York, New York, USA.

O'Brien, K. L., and R. Leichenko. 2000. Double exposure: assessing the impacts of climate change within the context of economic globalization. Global Environmental Change 10(3):221-232.

O'Brien, K. L., and R. Leichenko. 2003. Winners and losers in the context of global change. Annals of the Association of American Geographers 93 (1):89-109.

Ostrom, E., T. Dietz, N. Dolšak, P. C. Stern, S. Stovich, and E. U. Weber, editors. 2002. The drama of the commons. National Academy Press, Washington, D.C., USA.

Pauly, D., V. Christensen, J. Dalsgaard, R. Froese, and F. Torres, Jr. 1998. Fishing down marine food webs. Science 279:860-863.

Pauly, D., V. Christensen, G. Sylvie, T. Pitcher, R. Sumaila, C. Walters, R. Watson, and D. Zeller. 2002. Towards sustainability in world fisheries. Nature 418:689-695.

PERIKANAN. 2000. Kebijakan Strategis Sektor Kelautan dan Perikanan Kabupaten Donggala 2001-2005. PERIKANAN, Tingkat II, Palu, Sulawesi Tengah.

Peterson, G. 2000. Political ecology and ecological resilience: an integration of human and ecological dynamics. Ecological Economics 35:323-336.

PSL/UNTAD. 2000. Pengelolaan Terpadu Berbasis Masyarakat Kawasan Persisir di Banawa Selatan. Pusat Studi Lingkungan, Universitas Tadulako, Palu, Sulawesi Tengah.

Robbins, P. 2004. Political ecology. Blackwell, Malden, Maine, USA.

Ruitenbeek, J., and C. Cartier. 2001. The invisible wand: adaptive co-management as an emergent strategy in complex bio-economic systems. Centre for International Forestry Research, Occasional Paper No. 34, Bogor, Indonesia.

Scoones, I. 1999. New ecology and the social sciences: what prospects for a fruitful engagement? Annual Review of Anthropology 28:479-507.

Scott, J. C. 1998. Seeing like a state: how certain schemes to improve the human condition have failed. Yale University Press, New Haven, Connecticut, USA.

Sen, A. 1992. Inequality reexamined. Oxford University Press, Oxford, UK.

Soendjoto, M. A., and P. Arifin. 1999. Hutan mangrove desa Pegatan besar, Kalimantan Selatan: vegetasi dan manfaatnya bagi masyarakat. Jurnal Pusat Penelitian Linkungan Hidup 17(4):42-51.

Stepp, J. R., E. C. Jones, M. Pavao-Zuckerman, D. Casagrande, and R. K. Zarger. 2003. Remarkable properties of human ecosystems. Conservation Ecology 7(3):11. [online] URL: http://www.consecol.org/vol7/iss3/art11.

Speth, G., editor. 2003. Worlds apart: globalization and the environment. Island Press, Washington, D.C., USA.

Supriadi, D. 1999. Peranan Izin Lingkungan Dalam Mencegah Terjadinya Kerusakan Hutan Bakau (The Role of Environmental Permits in Preventing Degradation of Mangroves). Thesis. Padjadjaran University, Bandung, Indonesia.

Visser, L. E., editor. 2004. Challenging coasts: transdisciplinary excursions into coastal zone development. Amsterdam University Press, Amsterdam, The Netherlands.

Vitousek, P. M., K. A. Moony, J. Lubchecko, and J. M. Melillo. 1997. Human domination of Earth's ecosystems. Science 277:494-499.

Walker, B., S. Carpenter, J. Anderies, N. Abel, G. S. Cumming, M. Janssen, L. Lebel, J. Norberg, G. Peterson, and R. Pritchard. 2002. Resilience management in socio-ecological systems: a working hypothesis for a participatory approach. Conservation Ecology 6(1):14 [online] URL: http://www.consecol.org/vol6/iss 1/art14.

Whitten, A. J., M. Mustafa, and G. S. Henderson. 1987. The Ecology of Sulawesi. Gadjah Mada University Press, Yogyakarta, Indonesia.

Zimmerer, K., and T. J. Bassett, editors. 2003. 
Political ecology: an integrative approach to geography and environment-development studies. Guilford, New York, New York, USA. 